\title{
Recycling of metals: accounting of greenhouse gases and global warming contributions
}

\section{Damgaard, Anders; Larsen, Anna Warberg; Christensen, Thomas Højlund}

\section{Published in:}

Waste Management and Research

Link to article, DOI:

$10.1177 / 0734242 \times 09346838$

Publication date:

2009

Document Version

Peer reviewed version

Link back to DTU Orbit

Citation (APA):

Damgaard, A., Larsen, A. W., \& Christensen, T. H. (2009). Recycling of metals: accounting of greenhouse gases and global warming contributions. Waste Management and Research, 27(8), 773-780.

https://doi.org/10.1177/0734242X09346838

\section{General rights}

Copyright and moral rights for the publications made accessible in the public portal are retained by the authors and/or other copyright owners and it is a condition of accessing publications that users recognise and abide by the legal requirements associated with these rights.

- Users may download and print one copy of any publication from the public portal for the purpose of private study or research.

- You may not further distribute the material or use it for any profit-making activity or commercial gain

- You may freely distribute the URL identifying the publication in the public portal 
Accepted for publication in Waste management \& research

Recycling of metals: Accounting of greenhouse gases and global warming contributions

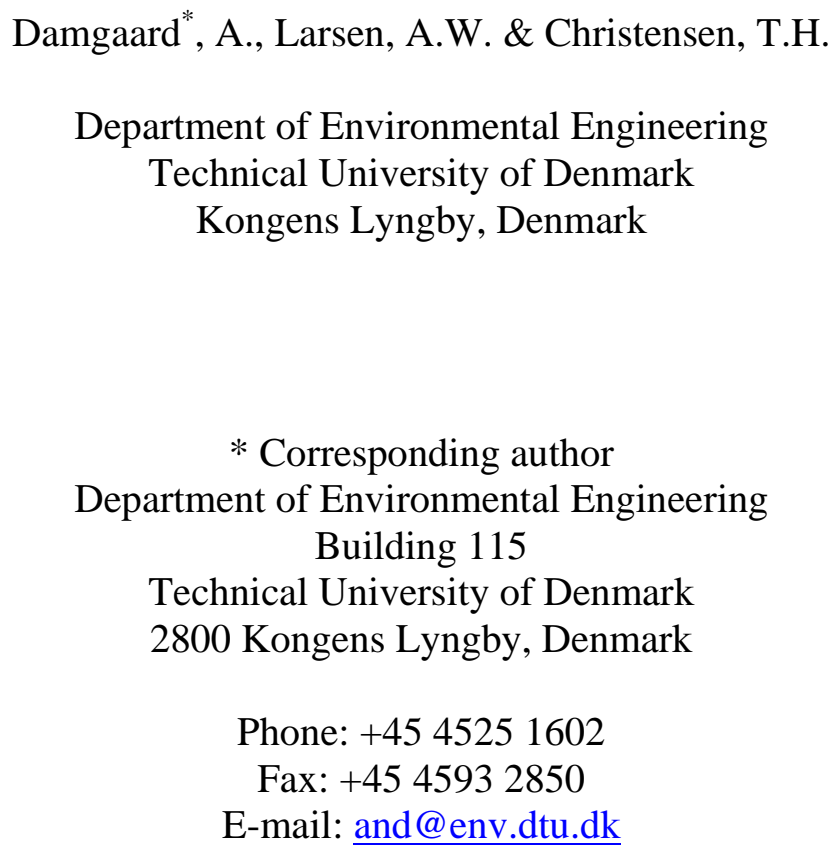

"NOTE: this is the author's version of a work that was accepted for publication in Waste Management \& Research journal. Changes resulting from the publishing process, such as peer review, editing, corrections, structural formatting, and other quality control mechanisms may not be reflected in this document. Minor changes may have been made to this manuscript since it was accepted for publication. A definitive version is published in Waste management \& research, vol 27(8), pp 773-780, doi: 10.1177/0734242X09346838” 


\begin{abstract}
Greenhouse gas (GHG) emissions related to recycling of metals in post-consumer waste are assessed from a waste management perspective; here the material recovery facility (MRF), for the sorting of the recovered metal. The GHG accounting includes indirect upstream emissions, direct activities at the MRF as well as indirect downstream activities in terms of reprocessing of the metal scrap and savings in terms of avoided production of virgin metal. The Global Warming Factor (GWF) shows that upstream activities and the MRF causes negligible GHG emissions (12.8 to $52.6 \mathrm{~kg} \mathrm{CO}$-equivalents per tonne recovered metal) compared to the reprocessing of the metal itself (360-1260 $\mathrm{kg} \mathrm{CO}_{2}$-equivalents per tonne of recovered aluminum and $400-1020 \mathrm{~kg} \mathrm{CO}_{2}$-equivalents per tonne of recovered steel).The reprocessing is however counterbalanced by large savings of avoided virgin production of steel and aluminum. The net downstream savings were found to be 5040 - $19340 \mathrm{~kg} \mathrm{CO}_{2}$-equivalents per tonne of treated aluminum and 560 - $2360 \mathrm{~kg} \mathrm{CO}$-equivalents per tonne of treated steel.
\end{abstract}

Due to the huge differences in reported data it is hard to compare general data on the recovery of metal scrap as they are very dependent on the technology and data choices. Furthermore it is crucial what energy is used both in the recovery process as well as the avoided primary production. The range of avoided impact shows that recovery of metals will always be beneficial over primary production, due to the high energy savings, and that the GHG emissions associated with the sorting of metals are negligible.

Key words: Recycling, metal, global warming, $\mathrm{CO}_{2}$ accounting, waste management, steel recycling, aluminum recycling, green house gases 


\section{Introduction}

Metal is a major fraction of waste; primarily as a fraction from demolition waste in terms of steel reinforcements etc, from end-of-life vehicles and from household appliances, secondly from the municipal waste stream in form of packaging materials such as cans, foil and containers. Metal scrap is divided into two categories; ferrous metal which consists of iron and steel; and non-ferrous metal which consists of everything else, such as aluminium, copper, lead, zinc, chromium and precious metals. As mentioned in the preface to this special issue (Christensen, 2009) the focus in the articles are on postconsumer waste. This means that the largest source of recycled metals, offcuts from industry, is not directly included in the article. It is though mentioned in the article where relevant.

The main reason for recycling of metals (ferrous and non-ferrous alike) is that the production of the virgin metal is extremely energy intensive. Recycling of scrap metals are in comparison a lot less energy demanding, for example does recycling of aluminium only use $5 \%$ of the energy used for virgin aluminium (IPPC, 2001). Another reason for recycling metals is that metals are limited resources and mineral ore is getting scarcer and more expensive to exploit.

Metals from industry and construction have traditionally been recycled as they were available in large quantities (mainly iron and steel), whereas the recycling of metals in municipal solid waste (MSW) has mainly increased over the last decade. Recycling of metals from MSW may occur as source separated fractions, from co-mingled waste that afterwards has been sorted mechanically, from waste-to-energy facilities where metals are removed from the bottom ash, and from mechanical-biological-treatment plants if including a metal sorting unit. Recycling of metals require that foreign elements are removed, and that the metals are sorted into their respective metal types.

The waste management of metal waste therefore includes collection, transport and sorting at a Material Recovery Facility (MRF). Recycling of metals thereby contributes to emission of GHG directly 
by combustion of fuel or indirectly by use of electricity. Indirect contributions may also include the consumption of products and materials for cleaning and packaging.

The purpose of this paper is to describe metal recycling from a global warming point of view and provide information about data useful in accounting of greenhouse gas emissions including the reprocessing of the waste metal and the avoided production of metals from virgin materials. The GHG accounting is done as suggested by Gentil et al. (2009) distinguishing between direct and indirect contributions.

\section{Overview of metal recycling technologies}

The following sections provide a general description of the waste management of metals (in this article exemplified by steel and aluminium) at an MRF, as well as the downstream processes for reprocessing and virgin manufacturing. The collection and transport of the recovered metals are in this article defined as upstream processes and they are not further described here. A description and data for collection and transport in relation to GHG accounting can be found in Eisted et al. (2009)

The reprocessing of steel involves electric arc furnace (EAF) or basic oxygen furnace (BOF) processes as described further in chapter 2.2. In 2007 the EAF production amounted to about $38 \%$ of the overall European production (IPPC, 2008). Before the actual reprocessing of the scrap metal a sorting is performed to remove contaminants as described in chapter 2.1.

Aluminium recycling can be divided into two groups: remelters and refiners. Remelters mainly use aluminium scrap directly from manufactures which can be directly remelted. Refiners use "old scrap” aluminium which comes from a variety of sources such as end-of-life vehicles, household goods and municipal solid waste (MSW). In 2004 the production from remelters in the EU25 was around 1.9 million tonnes, and the production from refiners around 2.8 million tonnes (EAA, 2007). We will focus on the 
technology used by the refiners in this article since this is where most of the post-consumer aluminium is treated.

\subsection{Material Recovery Facilities}

Metals in post-consumer waste can be separated into two categories. The household waste collected by the municipalities (primarily packaging waste), and the bulky waste which is collected and sent to a MRF. The majority of the metals are in the bulky waste fraction. The packaging waste can either be source separated in the households and collected and sent to a MRF or directly for recycling. Alternatively it can go with the residual waste stream to further treatment. This could be in a MBT (Mechanical Biological Treatment) where the metals are sorted out and sent to a metal MRF, or the residual waste could be sent to an incinerator. Here a part of the metals can be sorted out from the bottomash and sent to the MRF. The metals coming from here have a much lower quality due to incomplete burning etc. The bulky waste is collected either by the municipality or by scrap suppliers and sent to the MRF. The purpose of the MRF is to sort and upgrade the recovered material to a suitable quality grade for reprocessing. Large clean fractions of aluminium or steel are sent directly from the MRF to recycling. Bulky waste products with a large content of metals are sent to an electrical shredder which divides the large pieces into smaller cleaner metal and residual fractions that can be further mechanically sorted. The shredded waste is sent to drum magnets where the magnetic fractions is sorted out, followed by an eddy current separator where the aluminium is sorted of. In a third sorting step the remaining metals (Copper, brass, zinc, lead, magnesium etc.) glass and plastics are sorted out, the remaining residues after these treatment steps are sent to further treatment, most commonly either landfilling or incineration.

The main issue with respect to GHG is the use of fuels and energy at the MRF.

\subsection{Reprocessing of metals: recyclable steel and aluminium}


We have chosen to focus on two main metals, steel and aluminium, since they are the most abundant metals in the MSW. The main GHG issue associated with the recycling of these metals is the use of energy

\section{Steel recycling}

The BOF process accepts only 25-30\% of scrap steel, of which the majority comes from home scrap which is steel scrap originating from the production of the steel ingots/sheets/rolls themselves (cut offs from shaping etc.) or new scrap from cut offs from the shaping in steel product fabrication (IPPC, 2008). The EAF process on the other hand accept $100 \%$ steel scrap and this is where the majority of the postconsumer steel scrap ends up (IISI, 2005), the focus in the article is therefore on the EAF process.. The main steps of the EAF process are as follows. The scrap is first preheated with the off gas generated at latter steps in order to conserve energy (and optionally additional fossil energy can be added). Next the scrap is loaded in baskets together with lime used as a flux. The furnace anodes are then lowered into the scrap. The initial energy to the arcs is kept low, until they are fully submerged in the scrap at which point the energy is increased until complete melting. Oxygen can be added to the early stages of the melting to boost the process. When final temperature has been reached the liquefied steel is tapped into a ladle, and alloying and deoxidizing compounds are added. After this the steel is sent for casting into whatever final product is desired.

\section{Aluminium recycling}

Aluminium recycling mainly takes place in rotary or reverbatory furnaces, for very clean aluminium grades induction furnaces can be used but these take up a very small part of the aluminium recycling. For the aluminium from MSW such as used beverage cans and foils it is necessary to pre-treat the aluminium to remove contaminants and de-coat or de-oil the scrap depending on source. This improves the thermal 
efficiency of recycling, and reduces potential emissions from the melting process. The scrap is then loaded into the furnaces. There are a number of different furnace setups depending on the quality of the aluminium scrap. From the furnace the melted aluminium is tapped for either direct casting or sent to another furnace where alloys can be made. In this process the aluminium is also refined to remove the last impurities in the aluminium. The aluminium recycling process only uses around $5 \%$ of the energy needed for the virgin aluminium production, as the alumina conversion in virgin production is where the majority of the energy is used (EEA, 2008).

\subsection{Production steel and aluminium from virgin material}

Metal products produced from scrap are likely to substitute products with the same characteristics on the market, here assumed to be products produced from virgin iron ore or bauxite. Depending on the system choices, the recovered scrap metal could also be assumed to substitute recovered scrap from other areas and thereby including optional treatment of the recovered scrap. But since the consumption of both steel and aluminium is increasing these years it seems unlikely that the recovered scrap will substitute other recovered scrap. It is therefore assumed that the substituted processes will be virgin steel production and virgin aluminium production.

\section{Virgin steel production}

In traditional steel production iron ore is first melted in a blast furnace to produce a melted metal used in the BOF where it is converted to steel. The iron ore is mixed with flux material and coke, and is charged into the top of the blast furnace. The furnace is heated by the use of hot stoves, these stoves are heated to $1100-1500^{\circ} \mathrm{C}$ and cold air is then forced through the stoves thus creating the hot blast due to the expanding air which is fed into the blast furnace at a temperature of $900-1350^{\circ} \mathrm{C}$ (IPPC, 2008). The iron oxides and coke will hereby react and hot molten iron and slag are then tapped off from the bottom. The 
slag is removed from the molten iron with a skimmer, after which the molten metal is either cast or sent to steel production in torpedo ladles or transfer cars. If the molten metal is to be used for steel production it will first be sent to pre-treatment where contaminants of sulphur, phosphor and silicon will be removed. The molten metal is then sent to the basic oxygen furnace, where oxygen will be injected into the molten metal to produce an oxidizing reaction. When final temperature has been reached the liquefied steel is tapped into a ladle, and alloying and deoxidizing compounds are added. After this the steel is sent for casting into what final product is desired.

\section{Virgin aluminium production}

The production of virgin aluminium includes bauxite ore mining, alumina production, carbon anode production, aluminium smelting and ingot casting. The bauxite is converted to alumina via the Bayer process, which is a process where caustic soda is used to extract the alumina. This produces a slurry consisting of sodium aluminate and a mixture of metal oxides. The metal oxides are removed, and the alumina solution is cooled and seeded with alumina to crystallize hydrated alumina. The alumina is dissolved in a molten bath of sodium aluminium fluoride and through electrolytic reduction converted into aluminium. The Hall-Heroult process is a very energy intensive, and it is the main reason for the GHG emissions from the aluminium production. The molten aluminium is withdrawn from the conversion cells and transported to a casting plant where alloying additives are added. Finally the aluminium is cast into the final shape such as ingots, sheets or billets.

\section{Sources of GHG emissions}


The sources of GHG emissions from the steel and aluminium recycling are both direct and indirect. The emissions were identificed and quantified and presented in Upstream-Operation-Downstream (UOD) tables following the framework suggested by Gentil et al. (2009).

For waste management of metals the direct emissions cover onsite operation processes taking place at the MRF, whilst the indirect cover processes upstream and downstream which are affected by the operations at the MRF. In this section a comprehensive overview of the sources of GHG emissions from the processes are presented with the corresponding data. For the management of recovered steel and aluminium, as for many other operations, the GHG emissions are strongly connected to the energy conditions. Most GHG occur due to the use of fossil fuel based energy, either by combustion at the plant, by upstream processes providing the energy or by crediting in downstream processes. Moreover carbon dioxide occur from the oxidizing melting processes themselves when oxygen and carbon reacts. Polyfluorinated carbons (PFC) (such as tetrafluoromethane $\left(\mathrm{CF}_{4}\right)$ and hexafluoroethane $\left(\mathrm{C}_{2} \mathrm{~F}_{6}\right)$ ) are produced during anode effects from the electrolysis (IPPC, 2001), and this is also of huge concern as they are powerfull greenhouse gasses. As climate change has become a focus point on the political agenda and the consumer awareness is rising, the steel and aluminium industry have also become aware of their environmental profiles. Research efforts are therefore made and action is taken into reducing the energy use, exporting excess energy from the plants as well as converting from fossil fuel to renewable energy (IPPC, 2001). All these efforts have already and will in the future decrease the GHG emissions from steel and aluminium production further. In the following 3 subsections a comprehensive overview of the sources of GHG emissions from the processes are presented, both direct and indirect.

\subsection{Indirect upstream emissions}

The upstream processes in relation to the MRF has been identified to be provisions of electricity, provision of natural gas, provision of fuel oil, provision of diesel and construction of buildings, fixtures 
and other equipment (incl. raw material supply). The provision of these energy sources and materials are linked to the MRF, but as the production of them take place upstream of the MRF they are accounted for here. In the first column in Table 1 and 2 it can be seen which upstream emission sources has been accounted and not accounted. It was assumed that the mixed scrap was separated at the same type of MRF thus these numbers in the two tables are identical. GHG emissions data relevant for collection and transport of waste can be seen in Eisted et al. (2009) and are therefore not included in this paper.

Table 1 Greenhouse gas account and global warming factors for treatment of 1 tonne of scrap aluminium (wet weight) in a MRF.

\begin{tabular}{|c|c|c|}
\hline Indirect: Upstream & Direct: Waste Management & Indirect: Downstream \\
\hline $\begin{array}{l}\left.\text { GWF (kg } \mathrm{CO}_{2} \text { - eq. tonne }{ }^{-1} \mathrm{ww}\right) \text { : } \\
6 \text { to } 45,8\end{array}$ & $\begin{array}{l}\left.\text { GWF (kg } \mathrm{CO}_{2} \text { - eq. tonne }{ }^{-1} \mathrm{ww}\right) \text { : } \\
6.8\end{array}$ & $\begin{array}{l}\left.\text { GWF (kg } \mathrm{CO}_{2^{-}} \text {eq. tonne }{ }^{-1} \mathrm{ww}\right) \text { : } \\
-5040 \text { to }-19340\end{array}$ \\
\hline $\begin{array}{l}\text { GWF (kg CO }{ }_{2} \text { - eq. tonne }{ }^{-1} \text { ww): } \\
\text { - Provision of diesel: } 1-1.3(\mathrm{GWP}=1) \\
\text { - Provision of electricity: } 5-44.5 \\
\quad(\mathrm{GWP}=1)\end{array}$ & $\begin{array}{l}\left.\text { GWF (kg } \mathrm{CO}_{2} \text { - eq. tonne }{ }^{-1} \mathrm{ww}\right) \text { : } \\
\text { - Combustion of diesel in grab } \\
\text { cranes: } 6,8(\mathrm{GWP}=1)\end{array}$ & $\begin{array}{l}\left.\text { GWF (kg } \mathrm{CO}_{2} \text { - eq. tonne }{ }^{-1} \mathrm{ww}\right) \text { : } \\
\text { - } \text { Reprocessing and avoided virgin } \\
\text { production of } 950 \mathrm{~kg} \text { sorted } \\
\text { aluminium scrap } \\
\text {-5040 to }-19340(\mathrm{GWP}=1) \\
\text { Release of special emissions from } \\
\text { virgin production (included above): } \\
\text { - } \mathrm{CF}_{4}:-133 \text { to }-6651(\mathrm{GWP}=7390) \\
\text { - } \mathrm{C}_{2} \mathrm{~F}_{6}:-24.4 \text { to }-1220 \\
(\mathrm{GWP}=12200)\end{array}$ \\
\hline $\begin{array}{l}\text { Accounted (unit tonne }{ }^{-1} \mathrm{ww} \text { ): } \\
\text { - Provision of diesel: } 2.5 \text { liter } \\
\text { - Provision of electricity: } 50 \mathrm{kWh}\end{array}$ & $\begin{array}{l}\text { Accounted (unit tonne }{ }^{-1} \text { ww): } \\
\text { - Combustion of diesel in grab } \\
\text { cranes: } 2.5 \text { liter } \\
\text { - Use of electricity (shredder and } \\
\text { lighting): } 50 \mathrm{kWh}\end{array}$ & $\begin{array}{l}\text { Accounted (unit tonne }{ }^{-1} \mathrm{ww} \text { ): } \\
\text { - Reprocessing of } 950 \mathrm{~kg} \text { sorted } \\
\text { aluminium scrap } \\
\text { - Release of special emissions from } \\
\text { virgin production: } \\
\text { - } \mathrm{CF}_{4}: 0.018-0.9 \mathrm{~kg} \\
\text { - } \mathrm{C}_{2} \mathrm{~F}_{6}: 0.002-0.1 \mathrm{~kg}\end{array}$ \\
\hline $\begin{array}{l}\text { Not accounted: } \\
\text { - Provision of waste scrap } \\
\text { metal(Collection and transport) } \\
\text { - Construction of buildings, fixtures } \\
\text { and other equipment }\end{array}$ & $\begin{array}{l}\text { Not accounted: } \\
\text { - Consumption of packaging } \\
\text { material } \\
\text { - Consumption of lubricating oil } \\
\text { and other auxiliaries }\end{array}$ & $\begin{array}{l}\text { Not accounted: } \\
\text { - Long-haul transport of recovered } \\
\text { scrap to smelters } \\
\text { - Transport of residue material to } \\
\text { treatment plant } \\
\text { - Treatment of residue waste } \\
\text { material }\end{array}$ \\
\hline
\end{tabular}


Table 2 Greenhouse gas accounting and global warming factors for treatment of 1 tonne of scrap steel (wet weight) in a MRF.

\begin{tabular}{|c|c|c|}
\hline Indirect: Upstream & Direct: Waste Management & Indirect: Downstream \\
\hline $\begin{array}{l}\left.\text { GWF (kg } \mathrm{CO}_{2} \text { - eq. tonne }{ }^{-1} \mathrm{ww}\right) \text { : } \\
6 \text { to } 45,8\end{array}$ & $\begin{array}{l}\left.\text { GWF (kg } \mathrm{CO}_{2} \text { - eq. tonne }{ }^{-1} \mathrm{ww}\right) \text { : } \\
6.8\end{array}$ & $\begin{array}{l}\left.\text { GWF (kg } \mathrm{CO}_{2} \text { - eq. tonne }{ }^{-1} \mathrm{ww}\right) \text { : } \\
-560 \text { to }-2360\end{array}$ \\
\hline $\begin{array}{l}\left.\text { GWF (kg } \mathrm{CO}_{2} \text { - eq. tonne }{ }^{-1} \mathrm{wW}\right): \\
\text { - Provision of diesel: } 1-1.3(\mathrm{GWP}=1) \\
\text { - Provision of electricity: } 5-44.5 \\
\quad(\mathrm{GWP}=1)\end{array}$ & $\begin{array}{l}\left.\text { GWF (kg } \mathrm{CO}_{2} \text { - eq. tonne }{ }^{-1} \mathrm{ww}\right) \text { : } \\
\text { - Combustion of diesel in grab } \\
\text { cranes: } 6,8(\mathrm{GWP}=1)\end{array}$ & $\begin{array}{l}\left.\text { GWF (kg } \mathrm{CO}_{2} \text { - eq. tonne }{ }^{-1} \mathrm{ww}\right) \text { : } \\
\text { - Reprocessing and avoided virgin } \\
\text { production of } 980 \mathrm{~kg} \text { sorted steel } \\
\text { scrap: }-560 \text { to }-2360(\mathrm{GWP}=1)\end{array}$ \\
\hline $\begin{array}{l}\text { Accounted (unit tonne } \mathrm{e}^{-1} \mathrm{ww} \text { ): } \\
\text { - Provision of diesel: } 2.5 \text { liter } \\
\text { - Provision of electricity: } 50 \mathrm{kWh}\end{array}$ & $\begin{array}{l}\text { Accounted (unit tonne }{ }^{-1} \mathrm{ww} \text { ): } \\
\text { - Combustion of diesel in grab } \\
\text { cranes: } 2.5 \text { liter } \\
\text { - Use of electricity (shredder and } \\
\text { lighting): } 50 \mathrm{kWh}\end{array}$ & $\begin{array}{l}\text { Accounted (unit tonne } \mathrm{e}^{-1} \mathrm{ww} \text { ): } \\
\text { - Reprocessing of } 980 \mathrm{~kg} \text { sorted } \\
\text { steel scrap }\end{array}$ \\
\hline $\begin{array}{l}\text { Not accounted: } \\
\text { - Provision of waste scrap } \\
\text { metal(Collection and transport) } \\
\text { - Construction of buildings, fixtures } \\
\text { and other equipment }\end{array}$ & $\begin{array}{l}\text { Not accounted: } \\
\text { - Consumption of packaging } \\
\text { material } \\
\text { - Consumption of lubricating oil } \\
\text { and other auxiliaries }\end{array}$ & $\begin{array}{l}\text { Not accounted: } \\
\text { - Long-haul transport of recovered } \\
\text { scrap to smelters } \\
\text { - Transport of residue material to } \\
\text { treatment plant } \\
\text { - Treatment of residue waste } \\
\text { material }\end{array}$ \\
\hline
\end{tabular}

\subsection{Direct emissions}

The direct emissions come from the operations at the MRF. These are mainly from combustion of fuels used by the grab cranes at the MRF (6.8 l/tonne waste metal) see also the middle column in Table 1. Some direct emissions can also occur from combustion of fuel for heating purposes, commonly fuel oil or natural gas, the amounts were though found to be neglible. The electricity consumption in the shredder (50 kWh/tonne waste metal (H.J.Hansen, 2009)), is included in the middle column but the provision of the produced electricity and hence the emissions is allocated upstream and can be seen in the first column.

Most of the data found in the literature and databases present the data per tonne output. It is unlikely that the metals can be collected totally without any impurities nor be processed at the MRF without a small material loss. The data has therefore in this article been changed into a format which represents one tonne input to the MRF, which is consistent with the other technologies, which are presented in this special issue. To be consistent with the other special issue articles the amount is given in tonne wet weight, but in the case of metals the water content can be considered negligible.

The US EPA (2006) has reported material loss for aluminium recycling at 7\%, whereas the European Aluminum Association (EAA, 2008) reports numbers in the range of 2-3\% for cans and 4-6\% 
for old scrap in general. For processes found in other literature the documentation does not describe the material loss, thus an average of 5\% from above sources have been used for recalculations. Furthermore it was found that pre-treatment and sorting at the MRF of aluminium gave a loss before recycling of $4.8 \%$ (EAA, 2008). The overall loss of aluminium from it enters the MRF till the final ingot has been cast is therefore about $10 \%$ which has been used for recalculations. Loss in steel recycling was by the US EPA (2006) found to be 5\% which fitted well with documentation from the Ecoinvent database (Classen et al., 2007). Loss of steel in the MRF was found to be almost negligible, where information sources give values of 1-2\% (US EPA, 2006; Classen et al. 2007). Thus, 2\% was used for recalculations when needed.

\subsection{Indirect downstream emissions}

The downstream indirect emissions stem from utilization of the recovered scrap metal in the aluminium and steel smelters as well as treatment of the residues from the MRF. Depending on the system limitations the downstream indirect emissions can also include saved emissions from production of substituted products produced from virgin ore and bauxite. Figure 1 shows a flow diagram of the investigated system, and it illustrates where in the system the substitutions occur. Processes marked with dotted lines are not included in the calculations.

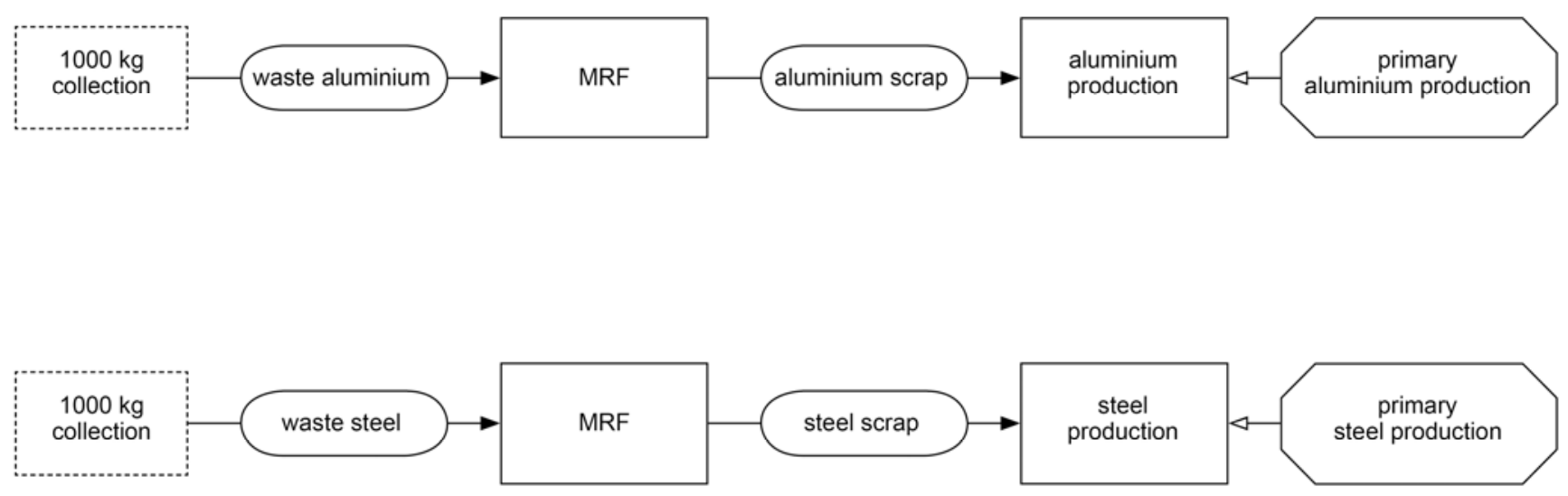

Figure 1 Flow diagram for recycling of aluminium and steel waste. Flow diagram for recycling of aluminium and steel waste. 
A lot of the data found had aggregated the downstream emissions for the reprocessing with the avoided virgin production emissions. It was therefore decided to keep these figures aggregated in the right column in table 1 and 2, even for those data where disaggregation was possible. As it can be seen in the right column in Table 1, it is only reprocessing of $950 \mathrm{~kg}$ recovered aluminium and $980 \mathrm{~kg}$ recovered steel that is included as a downstream process. The residue treatment options differ a lot, but GHG issues are minor in all cases. Thus they were not included. If it is a desire to include these, the $\mathrm{CO}_{2}$ emissions from recycling of slag in civil works as well as the emissions from landfilling of residues should be considered. Emissions from incineration and landfilling can be found in Astrup et al. (2009) and Manfredi et al. (2009).

\section{Estimation of GHG emissions}

GHG emissions for upstream, operational and downstream processes are estimated by the use of emission factors (EFs). An EF describes any emission from a process expressed as an amount emitted per characteristic unit. It may in some cases be aggregated from a range of different contributions and presented as $\mathrm{kg} \mathrm{CO}_{2}$-eq. per characteristic unit. In the case of aggregated $\mathrm{EFs}$, the GHG emissions have been converted to $\mathrm{CO}_{2}$-eq. by the use of global warming potentials (GWPs) as defined by the IPCC using a time horizon of 100 years (Solomon et al., 2007).

In this article the GHG emissions have been further aggregated into global warming factors (GWFs). This expresses the overall potential contribution to global warming from the upstream, operational and downstream process for the waste management technology expressed in $\mathrm{CO}_{2}$-eq./tonne of wet waste. We define the GWF as the sum of the products of non-aggregated and aggregated EFs and the corresponding GWP in terms of $\mathrm{kg} \mathrm{CO}_{2}$-eq./tonne wet waste. GWF's are positive when there is a contribution to global warming, and negative when constituting a saving. 
Table 3 presents a number of aggregated EFs that have been used for the estimation of direct and upstream indirect emissions from operational activities.

Table 3 Emission factors for provision and combustion of energy (Fruergaard et al. 2009)

\begin{tabular}{|l|l|}
\hline Type of process/emission & Emission factor \\
\hline Provision of diesel & 0.4 to $0.5 \mathrm{~kg} \mathrm{CO}_{2}$-eq. $\mathrm{L}^{-1}$ diesel \\
\hline Combustion of diesel & $2.7 \mathrm{~kg} \mathrm{CO} 2$-eq. $\mathrm{L}^{-1}$ diesel \\
\hline Provision of electricity & 0.1 to $0.9 \mathrm{~kg} \mathrm{CO}{ }_{2}$-eq. $\mathrm{kWh}^{-1}$ \\
\hline
\end{tabular}

The emission factors for electricity is very much dependent on the fuel mix used and whether or not there is co-generation of heat; thus it varies a lot from country to country as well as from technology to technology. The range given here does not represent the extremities, but a fairly low and a fairly high number. More details on fuel and energy provision and combustion of fuels can be found in Fruergaard et al (2009) which is another article in this special issue.

Environmental reports from aluminium and steel smelters are very limited It is therefore very hard to come by good data. Non-aggregated and well described data in databases and literature are often limited geographically to represent North America and northern and central Europe. This makes it difficult to assess the validity of the data for a broader scope and to assess how representative the data is in the view of recyclable scrap steel and aluminium being traded on a world market. Furthermore it is hard to compare the different data sources since energy plays such a huge role in scrap metal reprocessing, and the energy supply is so diverse, ranging from fully hydro-powered to fully coal powered aluminium and steel smelters. The data therefore reflect average energy profiles as reported in literature.

When steel and aluminium scrap is recycled there is both a material loss in the technology and a material quality loss. The material loss means that 1 tonne input of scrap metal does not give an output of 1 tonne of ingots, as material can be lost in sorting or pre-treatment steps. It is specific for each reprocessing technology how big this loss is. For the datasets represented here it ranges from 2 to $6 \%$. The material quality loss is the loss of quality due to the reprocessing of the scrap, as aluminium and steel 
might be partially oxidized (for instance in scrap from waste incinerators) and new metal has to be added in order to obtain the same quality. This means that the substitution ratio between recycled aluminium and steel and virgin aluminium and steel are commonly less than 1:1. The substitution ratio varies depending on what type of furnaces that is used for reprocessing, and where the metal scrap originates from. Another example on a quality loss is steel scrap metal recovered from tin cans from waste incinerators. Here the tin cover of the steel cans will have migrated into the steel itself, and new steel will need to be added (Smith et al., 2001; IPPC, 2001 \& 2008; EAA, 2008; US EPA 2006).

One of the very important steps of virgin aluminium production is the electrolysis steps where carbon anodes are used for melting the aluminate. This produces direct $\mathrm{CO}_{2}$ and $\mathrm{CO}$ emissions as well as the formation of the two PFCs, namely $\mathrm{CF}_{4}$ and $\mathrm{C}_{2} \mathrm{~F}_{6}$ which have huge global warming potentials. The release of the PFCs has been lowered considerably in the EU during the last 10 years, where reported values have dropped with approximately 60\% (IPPC, 2001). The reason for this is that modern plants release amounts of PFCs in the range of 0.02-0.1 kg per tonne aluminium, where more old-fashioned smelters can reach values of up to $1 \mathrm{~kg}$ PFCs per tonne aluminium (IPPC, 2001). As $\mathrm{CF}_{4}$ and $\mathrm{C}_{2} \mathrm{~F}_{6}$ have global warming potentials of respectively 7390 and 12200 (Solomon et al., 2007) the avoidance of some of these emissions will have a huge impact. This of course makes it even more beneficial to recycle the aluminium as these emissions are not released in the recycling process. Research is being carried out in developing inert anodes which will totally avoid the release of $\mathrm{CO}_{2}$ and PFCs from the electrolysis (IPPC, 2001; EAA, 2006). These new anodes will thereby remove the direct emissions related to this, but of course there will still be a huge energy demand for the electrolysis of alumina.

The global warming factors (GWF) for managing recovered scrap metals can be seen at the top of Table 1 and 2, which has been derived based on the data in Table 1, 2 and 3. The by far largest contribution in the account of the global warming factors is the downstream reprocessing. The actual waste management taking place at the MRF has only small direct GHG emissions of approximately 6.8 $\mathrm{kg} \mathrm{CO}$-equivalents/tonne recovered metal. These are as already mentioned due to diesel combustion in 
grab cranes. The low electricity and fuel use also results in low upstream indirect GHG emissions of approximately 6-45.8 $\mathrm{kg} \mathrm{CO}_{2}$-equivalents/tonne recovered metal. These mainly originate from the electricity provision. The spectrum for the GWF is wide for the downstream processes depending on which data sets are chosen and which downstream processes are included in the accounting. Furthermore is the GWF highly dependent on the energy data used for the reprocessing and virgin production. A good example on this is McMillan \& Keoleian (2009) which looked into the regional variances for virgin aluminium production where they found that it ranged from $7.07 \mathrm{~kg}$ CO2-eq/kg metal to $21.9 \mathrm{~kg}$ CO2eq $/ \mathrm{kg}$ metal. The main influence here was the energy provision. The downstream processes of the reprocessing itself presented here range from 360 - $1260 \mathrm{~kg} \mathrm{CO}$-equivalents per tonne of recovered aluminium and 400 - $1020 \mathrm{~kg} \mathrm{CO}$-equivalents per tonne of recovered steel. This production is assumed to avoid the production of the virgin steel and aluminium which would else have contributed with 6300 $19700 \mathrm{~kg} \mathrm{CO}$-equivalents per tonne of recovered aluminium and 1580 - $2760 \mathrm{~kg} \mathrm{CO}$-equivalents per tonne of recovered steel. (Smith et al., 2001; IPPC, 2001 and 2008; Fisher, 2006; US EPA, 2006; EpE, 2007; Öko-Institut, 2007; Classen et al., 2007). This gives a total saving for the downstream processes of 5.0 to19.3 tonne $\mathrm{CO}_{2} /$ tonne aluminium processed and 0.6 to 2.4 tonne $\mathrm{CO}_{2} /$ tonne steel processed

\section{Discussion}

Accounting of GHG emissions from waste management of recycling of metals varies depending on what reporting and accounting mechanism is chosen. However, no matter what approach is chosen it is vital for the outcome that the basic technical data are satisfactory.

The data for MRFs for metals in the literature are limited and the reported data are not always transparent. It is therefore hard to assess the quality and the representativeness of these data for the whole waste management industry dealing with recovered metals. If we assume that the data is representative, there is a second level of uncertainty added in converting actual energy uses to GHG emissions. It is in 
particular the electricity use that has a large variation of GHG data depending on the electricity mix used in the calculations. The most important elements for the waste management of metals, however, are the ones taking place downstream of the waste management. As the GHG emissions and GWF vary considerably for the waste management of metals, when including the indirect downstream contributions, it is questionable if it is reasonable for the recycling industry to accept that downstream data can be selected randomly. Since both the processing of the recyclable metal as well as the production of the virgin metal, take place in a variety of plants with no specific connection to the actual metals MRF it may be useful if a certain set of data was agreed upon and used by everyone within the waste management industry.

Indicators found in the literature often have the reprocessing as the main part of recovered metals management, which seems to be justifiable looking at the small relevance of the processes upstream to the reprocessing. Most previous studies agree that the energy demand for virgin metal production is larger than the energy demand from recycling due to the much higher energy demand of the virgin processes (see EAA 2006; IPPC 2001 and 2008). However the source of this energy is highly critical for calculating the related GWF, and it is seen that a number of the new smelters are located in areas where hydropower is readily available to avoid using more polluting energy sources. It is therefore very important to keep this in mind when doing the assessments.

A review of different literature and databases found that the GWF indicator range from a saving of 9.2 to a saving of 13.5 tonne $\mathrm{CO}_{2} /$ tonne aluminium processed and 0.7 to a saving of 1.8 tonne $\mathrm{CO}_{2} /$ tonne steel processed (Smith et al., 2001; Fisher, 2006; US EPA, 2006; EpE, 2007). The range for these GWFs falls within the range which can be found if data from Table 1 and 2 is used for calculating indicators (including upstream, operational and downstream data). The literature GWFs are of course highly dependent on the data and the choices made in relation to energy aspects. Most studies have assumed virgin metal substitution, and for studies where a substituted mix consisting of the distribution of yearly production of virgin and recycled steel were assumed these data were omitted. We feel that omitting these 
data is correct since the consumption of both aluminium and steel is ever increasing (IISI, 2005; IAI, 2007), but if the consumption of these metals should stabilize or even start to fall it would be necessary to start looking at the mix.

It is important to keep in mind that comprehensive data in the literature is limited and that the data that do exists is geographically limited to mainly Europe and North America. Since scrap metal is a market commodity that moves all over the world, the steel reprocessing plants and related energy provision that is relevant to use may change frequently. The same is valid for the avoided production of virgin metals provision. Thus the data should in principle be representative for a world average to be valid in a more generic assessment.

\section{Conclusions}

The GHG accounting for recycling of metals shows that the contributions to global warming may vary considerably for recycling of steel and aluminium, with large overall global warming factor savings (5.0 to19.3 tonne $\mathrm{CO}_{2}$ /tonne aluminium processed and 0.6 to 2.4 tonne $\mathrm{CO}_{2} /$ tonne steel processed). The reprocessing of the metals are contributing to the majority of the emissions, but it was found that this more than offset by the avoided virgin metal production. It was found that the waste management (collection and sorting) contributions to GW are negligible when compared to the reprocessing of the metals themselves. Especially when taking into account the avoided virgin production. This is especially due to a significantly lower energy use in the reprocessing of the metals, and also avoided process emissions (e.g. $\mathrm{CF}_{4}$ and $\mathrm{C}_{2} \mathrm{~F}_{6}$ ) in virgin production. In conclusion it is, even though there are huge variances and uncertainty in the emissions found, clear that recycling of metals is very beneficial. 


\section{References}

Astrup, T., Møller, J. \& Fruergaard, T. (2009) Incineration and co-combustion of waste: Accounting of greenhouse gases and global warming contributions. Waste Management \& Research, 27, DOI: 0734242X09

Christensen, T. H. (2009) Why a special issue on greenhouse accounting in waste management? Waste Management \& Research, 27, DOI: 0734242X09

Classen, M., Althaus, H.-J., Blaser, S., Scharnhorst, W., Tuchschmid, M. \& Jungbluth, N. (2007) Life Cycle Inventories of Metals. Final report ecoinvent v2.0 No. 10, Swiss Centre for Life Cycle Inventories, Duebendorf, Switzerland.

EEA (2007) Aluminium Recyclingm in Europe. The road to High Quality Products. European Aluminium Published by Association and Organisation of European Aluminium Refiners and Remelters. Accessed June 2009 from:

http://www.eaa.net/upl/4/default/doc/Aluminium\%20recycling\%20in\%20Europe\%20-\%202007.pdf

EAA (2008). Environmental Profile Report for the European Aluminum Industry. Life Cycle Inventory data for aluminum production and transformation processes in Europe. European Aluminum Association. April 2008.

Eisted, R., Larsen A.W. \& Christensen, T.H. (2009) Collection, transfer and transport of waste: Accounting of greenhouse gases and global warming contributions. Waste Management \& Research, 27, DOI: 0734242X09 
EpE (2007): Protocol for the quantification of greenhouse gases emissions from waste management activities. Version 2. Entreprises pour l'Environnement, Nanterre, France

Fisher, K. (2006) Impact of Energy from Waste and Recycling Policy on UK Greenhouse Gas Emissions - Final Report. Prepared by Environment Resource Management (ERM) for Department for Environment, Food and Rural Affairs (DEFRA), Oxford, UK. Accessed February 2009 from: http://randd.defra.gov.uk/Document.aspx?Document=WR0609_5737_FRP.pdf

Fruergaard, T., Ekvall, T. \& Astrup, T. (2009) Energy use and recovery in waste management and implications for accounting of greenhouse gases and global warming contributions. Waste Management \& Research, 27, DOI: 0734242X09

Gentil, E. C., Aoustin, E. \& Christensen, T.H. (2009) Waste management: Accounting of greenhouse gases and global warming contributions. Waste Management \& Research, 27, DOI: 0734242X09

H.J.Hansen (2009) H.J.Hansen Genvindingsindustri A/S - Carbon Dioxide Inventory, according to international standard ISO 14064-1:2006. H.J.Hansen Genvindingsindustri A/S, Odense, Denmark.

IAI (2007) Aluminum for Future Generations/2007 update. International Aluminum Institute. Haymarket, London, United Kingdom

IISI (2005) Steel: The Foundation of a Sustainable Future. Sustainability Report of the World Steel Industry 2005. International Iron and Steel Institute, Brussels, Belgium. 
IPPC (2001) Integrated Pollution Prevention and Control. Reference Document on Best Available Techniques in the Non Ferrous Metals Industries. December 2001. European Commision, Brussels, Belgium

IPPC (2008) Integrated Pollution Prevention and Control. Draft Reference Document on Best Available Techniques for the Production of Iron and Steel. Draft February 2008. European IPPC Bureau, Seville, Spain.

Manfredi, S., Scharff, H., Tonini, D. \& Christensen, T.H. (2009) Landfilling of waste: Accounting of greenhouse gases and global warming contributions. Waste Management \& Research, 27, DOI: 0734242X09

McMillan, C.A. \& Keoleian, G.A. (2009) Not all primary aluminum is created equal: Life cycle greenhouse gas emissions from 1990 to 2005. Environmental Science and Technology. Vol. 43, No. 5, $1571-1577$

Smith, A., Brown, K., Ogilvie, S., Rushton, K. \& Bates, J. (2001): Waste Management Options and Climate Change. Final report to the European Commission, DG Environment. Office for Official Publications of the European Communities, Luxembourg.

Solomon, S., Qin, D., Manning, M., Alley, R.B., Berntsen, T., Bindoff, N.L., Chen, Z., Chidthaisong, A., Gregory, J.M., Hegerl, G.C., Heimann, M., Hewitson, B., Hoskins, B.J., Joos, F., Jouzel, J., Kattsov, V., Lohmann, U., Matsuno, T., Molina, M., Nicholls, N., Overpeck, J., Raga, G., Ramaswamy, V., Ren, J., Rusticucci, M., Somerville, R., Stocker, T.F., Whetton, P., Wood R.A. \& Wratt, D. (2007) Technical Summary. In: Climate Change 2007: The Physical Science Basis. Contribution of Working Group I to the 
Fourth Assessment Report of the Intergovernmental Panel on Climate Change [Solomon, S., D. Qin, M. Manning, Z. Chen, M. Marquis, K.B. Averyt, M. Tignor and H.L. Miller (eds.)]. Cambridge University Press, Cambridge, United Kingdom and New York, NY, USA.

US EPA (2006): Solid Waste Management and Greenhouse Gases - A Life Cycle Assessment of Emissions and Sinks. 3rd Edition. United States Environmental Protection Agency, Washington DC, USA

Öko-Institut (2007): Global Emission Model for Integrated Systems (GEMIS) Version 4.42. Öko-Institut, Freiburg, Germany. 